\title{
COLONIAL RELIC OR DYNAMIC ORGANISATION? THE COMMONWEALTH OF NATIONS AND CONFLICT RESOLUTION
}

\author{
Jessica Rodger*
}

This article examines in detail the ability of the Commonwealth of Nations to resolve conflicts within or between its member States. The organisation has continually emphasised its focus on adaptability, hence the main question of this article is whether or not the Commonwealth has adapted sufficiently to deal with the new kinds of conflict predominant in the world today. After looking at the organisation itself, the article moves on to examine regional organisations and the way in which they have adapted their conflict resolution capabilities in recent years. Specific instances of the Commonwealth's involvement in conflict resolution are also examined. Finally, various recommendations are put forward regarding which areas the Commonwealth needs to work on in order to ensure that it is in fact a dynamic and adaptable conflict resolution body.

\section{INTRODUCTION}

It is difficult to find any kind of academic article written about conflict management today and not see some mention of either the need for the United Nations to change their methods or for other international organisations to take a more active conflict management role. Much of the focus in recent years has been on regional organisations and the increasing role they are playing in resolving conflict. However, there is also another international organisation which, although not specifically regional in nature, can play an important role in this new era of primarily internal conflicts. This organisation is the Commonwealth of Nations.

The Commonwealth is a group of 54 nations who hail from every continent on the planet and are linked by past connections with the British Empire. The organisation prides itself on its flexibility and adaptability, and is continually working to improve its effectiveness. This paper

This paper was completed as a requirement for a Masters of Laws at Victoria University of Wellington in 2001. The writer would like to thank Ian Macduff, Senior Lecturer at Victoria, for his supervision and assistance. 
focuses primarily on what the organisation can work on with respect to its conflict resolution capabilities. Since the modern Commonwealth was formed in 1949, the conflicts which it has had to deal with have changed dramatically. The fundamental question is therefore whether the organisation has lived up to its promise of being an adaptable organisation, and what possibly could be done to adapt it further.

Part II will give a brief overview of how the Commonwealth works and its legal basis for action. Part III focuses on the changing nature of conflict and the ways in which regional organisations have come into their own in recent years. Two regional organisations, the Organisation for Security and Cooperation in Europe (OSCE) and the Association of South East Asian Nations (ASEAN) will be looked at in detail to illustrate how other organisations have adjusted to the new conflict patterns. In Part IV, Commonwealth involvement in recent conflicts in Sierra Leone, the Solomon Islands and Sri Lanka will be examined. Finally, Part V will go on to evaluate the Commonwealth's conflict resolution procedures and recommend ways in which the organisation can improve.

\section{THE ORGANISATION}

\section{A What is the Commonwealth?}

The task of explaining the Commonwealth of Nations is not as simple as it may seem. We can say that it is an organisation of governments, therefore making it an intergovernmental organisation, but what does this really tell us? The Commonwealth has no official constitution, hence an actual definition for the organisation can prove elusive. However, for our purposes, the Singapore Declaration of Commonwealth Principles provides an introductory explanation. This document states that the Commonwealth is "a voluntary association of independent sovereign states each responsible for its own policies, consulting and co-operating in the common interests of their peoples and in the promotion of international understanding and world peace". ${ }^{2}$

The organisation consists of 54 member nations, all of whom are connected by the fact that they have all, at some time, come under some direct or indirect form of British rule. ${ }^{3}$ For many, this may appear a strange basis for forming a group. Surely once a nation achieves its autonomy it would wish to cut all ties with the previous authority? The fact that this is not so, and that the Commonwealth continues to function as an international organisation, is testimony to the benefits which member States gain from the association.

As stated above, the Commonwealth lacks a formal constitution which sets out its purposes and procedure. However, there are three key documents which have gone a long way towards clarity.

2 Declaration of Commonwealth Principles (Singapore 1971) in The Commonwealth at the Summit: Communiques of Commonwealth Heads of Government Meetings 1944-1986 (Commonwealth Secretariat, London, 1987) 156.

3 The Commonwealth <http://www.thecommonwealth.org $>$ (last accessed 25 November 2001). 
The first is the Singapore Declaration which was adopted by the 1971 Heads of Government Meeting and sets out the fundamental principles on which the Commonwealth is based. The Declaration sets out such aims as "the security and prosperity of mankind", "equal rights for all citizens" and "the freest possible flow of international trade on terms fair and equitable to all". As well as setting out these aims, it also discusses the nature of the Commonwealth, in particular focusing on the role of co-operation, consultation and the exchange of knowledge as key aspects to the working of the organisation. ${ }^{4}$

When it comes to the nuts and bolts of the organisation we turn to the Agreed Memorandum on the Commonwealth Secretariat for enlightenment. This instrument was adopted when the Secretariat was established in 1965. This must be seen as a major step forward for the Commonwealth, as it would be hard to imagine that the organisation would be able to perform half the functions it does today without an administrative centre. There are several important basic details which can be gleaned from the document with respect to the Commonwealth generally. First, the Memorandum emphasises the informality of the organisation, and the respect that all members place on sovereignty. Secondly, it was recognised that in order to be an effective international organisation, the Commonwealth had to work in conjunction with other international organisations. Thirdly, there was a major focus on the Commonwealth being a living organisation, one willing and able to adapt to changing circumstances. ${ }^{5}$ This focus on informality and adaptability may help explain why there is no formal constitution.

More progress was made at the 1991 Heads of Government Meeting in Zimbabwe, where the third key document, the Harare Commonwealth Declaration, was adopted. This declaration is in large part simply a confirmation of the principles agreed on in Singapore in 1971. However, it is more specific with regard to what issues are of concern, and how it plans to deal with them. For example, the Harare Declaration lists the rights of women as an important priority, whereas the Singapore Declaration merely mentioned the "equality of all citizens". In Harare, the heads of government also saw fit to specifically mention the situation in South Africa as an issue of concern, along with numerous other issues such as drug trafficking and protection of the environment. ${ }^{6}$ The Harare Declaration is a clear illustration that the Commonwealth is taking seriously the commitment it made in the Agreed Memorandum to be flexible and move with the times.

4 Declaration of Commonwealth Principles, above, 156.

5 Agreed Memorandum on the Commonwealth Secretariat (London, 1965) in The Commonwealth at the Summit: Communiques of Commonwealth Heads of Government Meetings 1944-1986 (Commonwealth Secretariat, London, 1987) 105.

6 Harare Commonwealth Declaration (Harare, 1991) in Commonwealth Yearbook 2002 (Commonwealth Secretariat, London, 2001) 32. 


\section{B How does the Commonwealth work?}

When explaining how the Commonwealth works it makes sense to start with the Secretariat. This unit serves as the focal point for all administrative work done by the Commonwealth, and is the base for the Secretary-General. It organises Heads of Government Meetings, Ministerial Meetings, and co-ordinates efforts to put into effect decisions made at these meetings. Probably most important, however, is the fact that the Secretariat provides the Commonwealth with a hub, where individuals from member States interact daily and domestic information relevant to other member nations can be passed on efficiently and informally. ${ }^{7}$ Furthermore, the establishment of the Secretariat has led to major developments in the area of consultation with other international organisations, to the extent that there are Secretariat offices in New York and Geneva to provide easy access to the United Nations where the Commonwealth has observer status. ${ }^{8}$

One cannot discuss the role of the Secretariat without discussing the position of SecretaryGeneral. Not only is he the frontperson for the organisation, but he has numerous other responsibilities. ${ }^{9}$ Obviously, as with the United Nations, the role played by the Secretary-General will vary depending on the individual. Procedurally, however, the conceived role of the SecretaryGeneral was set out in the Agreed Memorandum. It was to be a position which demanded complete impartiality, with the needs of the Commonwealth put firmly at the forefront. It is clear from reading the Memorandum that the Secretary-General has a large degree of discretion. Although the Memorandum sets out some specific tasks which the Secretary-General must perform, such as visiting member countries, a large amount is left up to the individual. ${ }^{10}$

It is undeniable that, despite the huge amount of progress made by the Secretariat, it is the Commonwealth Heads of Government Meetings (CHOGMs) which often provide the most valuable forum for consultation within the Commonwealth. There is no document stating when and how CHOGMs are to occur, but a quick browse of recent years shows that they take place in a different member country every two years. The most recent CHOGM took place in March 2002 on the Sunshine Coast in Queensland, Australia. ${ }^{11}$ The consultations are not covered by media, though

7 Andrestinos N Papadopoulos Multilateral Diplomacy Within the Commonwealth (Martinus Nijhoff Publishers, The Hague, 1982) 99.

8 Dr Peter Slinn "The Commonwealth and the Peaceful Settlement of Disputes" (1989) 15 Comm LB 573, 578 .

9 The current Commonwealth Secretary-General is former New Zealand Minister of Foreign Affairs and Trade, Don McKinnon.

10 Agreed Memorandum on the Commonwealth Secretariat (London, 1965) in The Commonwealth at the Summit: Communiques of Commonwealth Heads of Government Meetings 1944-1986 (Commonwealth Secretariat, London, 1987) 105.

11 CHOGM $2002<\mathrm{http}: / /$ www.chogm2002.org $>$ (last accessed 20 September 2001). 
there is a statement issued at the end of each meeting setting out what was discussed and agreed on. As opposed to the United Nations, there is no voting, and all decisions are made by consensus. ${ }^{12}$

The benefits of this opportunity for heads of government to sit down and discuss relevant issues have been much documented. The lack of media and the informal nature allow for free and frank discussion among members. ${ }^{13}$ The speeches given by each Head of Government at the beginning of the conference allow the passing on of important domestic information which could be vitally important to other States, and to the international community as a whole. ${ }^{14}$ Finally, the opportunity to make a communal final statement, dealing with current issues, and with the support of 54 nations, cannot be under-rated as a tool for international influence.

As already mentioned, the Secretariat and the CHOGMs are not the only avenues for Commonwealth consultation. Numerous conferences take place on various issues including health, technology, finance and development, and involve ministers and experts in those particular fields. A more recent development is that of judicial colloquia. These are annual meetings of eminent jurists from Commonwealth countries who take the opportunity to discuss human rights issues within the Commonwealth. The first meeting was held in 1988 and ten years later a statement that has come to be referred to as the Bangalore Principles was issued by the colloquium, setting down fundamental human rights norms for the Commonwealth. ${ }^{15}$ As well as these established meetings there are also informal meetings of ministers and representatives which occur on an adhoc basis, as well as visits of the Secretary-General to various countries. Therefore, although the activities of the Commonwealth may not attract the media coverage or world-wide attention which the United Nations receives, one cannot suggest that it is at all a redundant or ineffective body.

\section{The Commonwealth as an International Organisation}

When we look at international organisations today it is fairly easy to label them: the Organisation of American States (OAS), European Union (EU) and Organisation for Security and Cooperation in Europe (OSCE) are regional organisations, the World Trade Organisation (WTO) is an international organisation concerned with trade issues, and Amnesty International is an international non-governmental organisation. And the list goes on. So what label does the

12 Dr Peter Slinn "The Commonwealth and the Peaceful Settlement of Disputes" (1989) 15 Comm LB 573, 577.

13 Andrestinos N Papadopoulos Multilateral Diplomacy Within the Commonwealth (Martinus Nijhoff Publishers, The Hague, 1982) 120.

14 Davidson Nicol "International Co-ordination within the United Nations: The Role of the Commonwealth" in Berhanykun Andemicael (ed) Regionalism and the United Nations (Oceana Publications Inc, New York, 1979) 106.

15 Lord Lester "The Challenge of Bangalore: Making Human Rights a Practical Reality" (1999) 3 EHRLR $273,273$. 
Commonwealth fit? It is an international organisation, though not truly international in that not all States belong. It is not devoted to any particular issue but concerns itself with a broad range. It is not regional as member nations hail from every continent on the planet. Can it be that the Commonwealth is a truly unique organisation?

One organisation which springs to mind as being similar to the Commonwealth, in that it is not easy to categorise, is the Non-Aligned Movement. This group of 117 States also includes 37 Commonwealth nations. ${ }^{16}$ Like the Commonwealth, the Non-Aligned Movement draws its membership from all over the world. It has similar aims to the Commonwealth, including the promotion of human rights, development and sovereignty. ${ }^{17}$ Probably the key difference between these two organisations is the way they were created. The Commonwealth came about gradually as former colonies became nations, but desired to retain contact with other Commonwealth States. The Non-Aligned Movement, however, came about due to a need for developing countries to get their voices heard within the United Nations system. Member States give full respect to the principles of the United Nations Charter and see the United Nations as a tool through which they can attain their development goals. ${ }^{18}$

Although we can make an argument that the Commonwealth and the Non-Aligned Movement have several things in common, we still need to know where they fit within the international picture. With respect to the Commonwealth it seems best to see the organisation as very similar to a regional organisation, in that it deals with the entire range of issues which concern its member States. The only difference is that the member States can be half a world away from one another. However, not only does the Commonwealth have much in common with contemporary regional organisations, especially with respect to conflict resolution, but it also serves as an invaluable connection between them. Members of the Commonwealth are also members of the OAS, ASEAN, the EU and NATO, to name a few. ${ }^{19}$ This serves as a major benefit to the Commonwealth, and indeed to the international community, as it encourages co-operation and consultation between regional organisations. As more and more commentators take the view that regional organisation is the way forward, ${ }^{20}$ this must mean that the Commonwealth also has an opportunity to take on a more enhanced role.

16 Non-Aligned Movement <http://www.nam.gov.za/background/index.html $>$ (last accessed 27 November 2001).

17 Non-Aligned Movement, above.

18 Non-Aligned Movement, above.

19 Davidson Nicol "International Co-ordination within the United Nations: The Role of the Commonwealth" in Berhanykun Andemicael (ed) Regionalism and the United Nations (Oceana Publications Inc, New York, 1979) 99.

20 Paul Martin "Regional Efforts at Preventative Measures: Four Case Studies on the Development of Conflict Prevention Capabilities" (1998) 30 NYU J Int'l L \& Pol 881, 895. 
We cannot leave this discussion without looking at the relationship between the Commonwealth and the United Nations. Although we can suggest that the Commonwealth is very similar to a regional organisation, it clearly does not come under Chapter VIII of the Charter which deals with "regional arrangements". However, this chapter can provide us with an excellent guide of how the Commonwealth/United Nations relationship should function. Clearly the United Nations has recognised the value of coordination with the Commonwealth, as it was granted observer status in 1976. ${ }^{21}$ The development of the Commonwealth as an effective international organisation can do nothing but aid the United Nations. Any problem, whether it be related to development, conflict or economies, within a member State which the Commonwealth can assist with, means a lightening of the load for the United Nations.

Therefore, although it may not be easy to pigeonhole the Commonwealth, or even to define it, it is easy to say that it is in many ways an effective international organisation. Its machinery, consultation procedures and membership suggest that the scope of its effectiveness can only continue to develop. The key area with which this paper is concerned is conflict resolution. The next chapter will go on to discuss briefly the dramatic ways in which conflict patterns have changed in recent years, before turning to look at how regional organisations have adapted to this change, and what lessons can be learnt by the Commonwealth.

\section{REGIONAL ORGANISATIONS}

Although it has not yet been ten years since former United Nations Secretary-General Boutros Boutros Ghali issued his "Agenda for Peace", in which he called for greater cooperation between his organisation and smaller, regional organisations, it seems his plan has already come to fruition. Even by 1995 in his "Supplement to An Agenda for Peace", he noted that there had been progress. ${ }^{22}$ One only needs to scan the newspaper headlines to see that regionalism is in full swing. For the purpose of this paper, it is important to see why regional organisations have risen to prominence so quickly, and what lessons the Commonwealth can learn from this trend.

\section{A Why have Regional Organisations Risen to Prominence?}

Part of the reason why regional organisations have come into their own can be traced back to the changes in conflict patterns in recent years. Numerous articles have discussed how the world is no longer the same as it was before or during the Cold War. For the purposes of analysing regional and Commonwealth approaches to conflict resolution, three main points must be noted. First, conflicts today are more likely to be internal than international. In the 1990 s, for instance, there were only

21 Nicol, above, 98.

22 Boutros Boutros Ghali "Supplement to An Agenda for Peace" (1995) < http://www.un.org/Docs/SG/ agsupp.html $>$ (last accessed 6 June 2001). 
twenty inter-state conflicts and over 100 internal wars. ${ }^{23}$ A second and related point is that these conflicts often involve a blurring of the distinction between combatants and non-combatants, increased use of guerilla warfare, ${ }^{24}$ and an increased likelihood of transnational and criminal involvement. ${ }^{25}$ Thirdly, there has been a major increase in the amount of conflict caused, either in whole or in part, by religious or ethnic factors. ${ }^{26}$ Such conflicts pose complex problems for third party mediators who need to have a thorough understanding of the cultural background before they can attempt to intervene.

Largely as a result of these dramatic changes, the United Nations' reputation in the conflict resolution arena has suffered severe damage over the last decade. The United Nations dealt with less than one-third of all conflicts in the 1990s. ${ }^{27}$ This fact is one of the key reasons why regional organisations have become so popular and effective. Many organisations have now focused their activities on conflict resolution, and have developed specific conflict resolution machinery. Just one example of such an organisation is the Organisation for Security and Cooperation in Europe (OSCE). They recognised that if they wanted to keep their region peaceful they could not always rely on the United Nations and, in fact, might even do a better job themselves.

There are numerous reasons why the United Nations has failed to fully deal with the new conflict patterns, though there are three of key importance to this discussion. First, the work of the United Nations is based on the matrix of international law, and most of the key international legal documents relating to conflict were not drafted with internal conflicts in mind. ${ }^{28}$ Many regional constitutive documents have been drafted more recently, however, and have focused on civil conflicts. Secondly, the United Nations simply does not have the financial backing to go running into the fray whenever a conflict is rumored. On the other hand, some regional organisations are very well resourced. ${ }^{29}$ Secondly, a United Nations operation requires the full support of member

23 Dan Smith "Trends and Causes of Armed Conflict" <http:// www.berghof-center.org/handbook> (last accessed 27 April 2001).

24 Binaifer Nowrojee "Recent Development: Joining Forces : United Nations and Regional Peacekeeping Lessons from Liberia" (1995) 8 Harv Hum Rts J 129, 129.

25 Report of the Panel on United Nations Peace Operations (Brahimi Report) <http://www.un.org/peace/ reports/peace_operations/report.htm> (last accessed 25 November 2001).

26 Peter Wallensteen "Global Patterns of Conflict and the Role of Third Parties" (1992) 67 Notre Dame L Rev $1409,1415$.

27 Report of the Panel on United Nations Peace Operations (Brahimi Report) <http://www.un.org/peace/ reports/peace_operations/report.htm> (last accessed 25 November 2001).

28 Stephen R Ratner "Does International Law Matter in Preventing Ethnic Conflict?" (2000) 32 NYU J Int'l L \& Pol 591, 593.

29 Paul Martin "Regional Efforts at Preventative Measures: Four Case-Studies on the Development of Conflict-Prevention Capabilities" (1998) 30 NYU J Int'l L \& Pol 881, 883. 
States in order to be successful. ${ }^{30}$ United Nations members are becoming more and more reluctant to commit funds, resources and overall political support to operations, for various reasons. ${ }^{31}$ However, when working on a regional level, it appears States are more willing to get involved.

As well as these three reasons why regional organisations may be better placed than the United Nations to deal with conflicts, Martin has highlighted three further factors which have contributed to the popularity of regional organisations. ${ }^{32}$ First, member States are more likely to have an interest in preventing conflicts in their region, which makes them more likely to intervene. Secondly, States in the region will generally be more sensitive, culturally and politically, to the problems in the conflicting states or state. Thirdly, they are normally closer geographically and also have closer relationships with the country (or countries) in question. They can therefore act swiftly and do not have to spend time cultivating relationships with those they need to deal with. ${ }^{33}$

It is therefore fairly clear why regional organisations are proving so effective. But is regionalism a positive development? There are several arguments in the affirmative. The development of regional groupings, for example, enables greater cooperation and more open relationships between States, which in itself can help to prevent conflict. ${ }^{34}$ In most cases regional organisations also put emphasis on diplomatic rather than military methods of resolving conflicts between their members. ${ }^{35}$ Another positive aspect is that regionalism is another way in which smaller States can have more influence on global affairs.

However, although most see the proliferation of regional organisations as a positive step, there are still some concerns. Three problems which Martin points out are inequality between regions which could lead to some regions being vulnerable to others; the use of regional organisations as a cover to prevent conflicts from being subject to international investigation; and the danger that States may find themselves with conflicting obligations as a result of belonging to several organisations. ${ }^{36}$ Some are also concerned that regional organisations may not be in a strong enough

30 Report of the Panel on United Nations Peace Operations (Brahimi Report) <http://www.un.org/peace/ reports/peace_operations/report.htm $>$ (last accessed 25 November 2001).

31 Binaifer Nowrojee "Recent Development: Joining forces: United Nations and Regional Peacekeeping lessons from Liberia" (1995) 8 Harv Hum Rts J 129, 133.

32 Martin, above, 883.

33 Martin, above, 883.

34 Martin, above, 884

35 Captain Davis Brown "The Role of Regional Organisations in Stopping Civil Wars" (1997) 41 A FL Rev $235,236$.

36 Martin, above, 885-886. 
position to take a United Nations-type role, especially with regard to peacekeeping. ${ }^{37}$ Although these concerns are valid, they would seem to support a cautious approach to regional involvement in conflict resolution, rather than an argument that regional organisations should not be involved at all.

\section{B Legal Basis for Regional Action}

Chapter VIII of the United Nations Charter specifically deals with the legal position of regional organisations in the international community. Article 52 accepts that regional organisations can deal with matters of international peace and security, as long as the action taken is not contrary to the purposes and principles of the United Nations. Article 52(2) emphasises that pacific methods of resolution must be favoured. Article 53 goes on to contemplate the situations in which regional organisations may wish to take enforcement action, and stipulates that they must have prior Security Council approval. Finally, in Article 54, the Charter points out that the Security Council must be kept fully informed of all action taken by regional organisations with respect to international peace and security.

As well as Chapter VIII there are other articles in the Charter dealing with regional organisations, including Article 56, relating to States taking "joint and separate action", and Article 33(1) which provides that recourse to regional organs may be the first step in resolving disputes. Despite these provisions the Charter has been criticised for being vague and ambiguous with respect to regional organisations. ${ }^{38}$ What is important, however, is whether the organisations involved have been able to get over these hurdles. Boutros Boutros Ghali obviously thought it was possible, and probably did much to assist in setting out five ways in which he felt the United Nations and regional organisations could work together. ${ }^{39}$ I will now move on to look at two particular organisations, the OSCE and ASEAN, to evaluate how successful they have been in adjusting to the new era of conflict within the existing legal regime.

\section{Case Studies: OSCE and ASEAN}

\section{The Organisation for Security and Cooperation in Europe}

With 55 members, including four of the five nuclear weapon States, the Organisation for Security and Cooperation in Europe (OSCE) has become a major player on the international stage. ${ }^{40}$ In many respects, it has much in common with the Commonwealth, ranging from its institutional structure to its focus on diplomacy and consensus. This in itself makes it a useful analogy when

37 Binaifer Nowrojee "Recent Development: Joining Forces: United Nations and Regional Peacekeeping Lessons from Liberia" (1995) 8 Harv Hum Rts J 129, 130.

38 Nowrojee, above, 132.

39 Boutros Boutros Ghali "Supplement to An Agenda for Peace" (1995) < http://www.un.org/Docs/SG/ agsupp.html $>$ (last accessed 6 June 2001).

40 Organisation for Security and Cooperation in Europe <http://www.osce.org > (last accessed 18 June 2001). 
looking at the Commonwealth and its ability to resolve conflicts. Even more useful is the fact that the OSCE appears to have been extremely successful in developing its conflict prevention machinery, and has now taken a leading role in conflict management in Europe.

The organisation itself did not come into being officially until 1995. Prior to that, it existed as the Conference on Security and Cooperation in Europe (CSCE). The Conference was forced to make some fundamental changes when the Cold War ended and it was saddled with the problems of a dissolving communist bloc. The organisation developed more concrete stuctures for dealing with problems, as opposed to simply having meetings of heads of government every two or three years. The changes in the way the body worked were eventually recognised in the Budapest Document produced at the 1994 Summit Meeting. To begin with, the body officially changed its name from Conference to Organisation, thereby recognising its more institutionalised nature. ${ }^{41}$ The document also recognised new areas of concern which makes it similar to the Commonwealth's Harare Declaration. Most importantly, the Budapest Document established the OSCE as "a primary instrument for early warning, conflict prevention and crisis management in the region". ${ }^{42}$

The way in which the OSCE works is in many ways similar to the Commonwealth. The meetings of heads of state allow the organisation to set its priorities, and receive reports from other sections of the OSCE. Decisions made at these meetings must generally be reached by consensus, with only a few exceptions. ${ }^{43}$ In between these usually bi-annual meetings a Permanent Council sits in Vienna, and meets on a weekly basis. There is also a Secretariat which provides operational support for the organisation and is headed by a Secretary-General. However, the OSCE itself is headed by a Chairman in Office (CIO), who "bears overall responsibility for executive action and co-ordination of OSCE activities". ${ }^{4}$

In terms of the OSCE's commitment to conflict prevention there are several aspects of the organisation which play a key role. Many feel that the High Commissioner on National Minorities (HCNM) is most important. ${ }^{45}$ The High Commissioner and his staff are empowered to conduct onsite missions in areas where it is felt that ethnic tensions have the potential to flare into conflict. ${ }^{46}$ In fact the CIO and Secretariat are currently overseeing the work of over 4,000 staff working "on the

41 Budapest Document (Budapest 1994) <http://www.osce.org/docs/english/1990-1999/summits/ buda94e.htm $>$ (last accessed 25 November 2001).

42 Budapest Document, above.

43 Michael Murray "The Language of Avoidance: How Human Rights Issues are Constrained by the Rhetoric of Non-Western Participants in the OSCE" (1997) 9 Int'l Legal Persp 227, 235.

44 Organisation for Security and Cooperation in Europe < http://www.osce.org > (last accessed 18 June 2001).

45 Paul Martin "Regional Efforts at Preventative Measures: Four Case-Studies on the Development of Conflict-Prevention Capabilities" (1998) 30 NYU J Int'l L \& Pols 881, 893.

46 Organisation for Security and Cooperation in Europe, above. 
ground" in various member States of the OSCE. ${ }^{47}$ The focus of such missions, whether sent by the HCNM or another official, is usually to establish dialogue between conflicting parties and ascertain first-hand the facts of any given situation.

Although the OSCE is seen by many as the ideal regional security organisation, it is not without problems. Some have criticised the OSCE for not dealing adequately with human rights issues. It is suggested that the organisation focuses only on those issues which are non-controversial, while leaving to the side the human rights problems which need urgent attention. ${ }^{48}$ Although the OSCE has gone to much effort to put in place procedures for dealing with human rights violations, it appears that the formality of the procedures in many ways prevents practical assistance being given. 49

Related to this criticism is the idea of consensus decision-making. Although it has its benefits, in that decisions made by the OSCE have the backing of 55 States, it can restrict the organisation's practical effect. However, it must be noted that, as the OSCE becomes more institutionalised, as with the HCNM, the consensus principle is gradually eroded with power being delegated to individuals and bodies. ${ }^{50}$ There is also some concern about the "soft law" nature of OSCE agreements. It is felt that governments see these agreements as providing them with a degree of flexibility should they be violated. Despite this, most scholars are of the opinion that a breach of such an agreement will still be seen by other OSCE members as a breach of international law. ${ }^{51}$

Taking these criticisms into account, how well has the OSCE really adapted to the changing face of conflict? In short, it appears to have adapted very well. The establishment of the HCNM in 1992 clearly illustrated that the OSCE States recognised where many of the current conflicts were stemming from. The HCNM himself, a former foreign minister for the Netherlands, has been a very successful mediator and representative for the OSCE. He appears to have a deeper understanding of the conflicts, and apply more suitable procedures, than many of his United Nations counterparts. ${ }^{52}$ As a result, he, and the organisation as a whole, have become greatly respected in the conflict prevention arena. Furthermore, the Chairman in Office (CIO) is seen as having more credibility than the United Nations Secretary-General, as the CIO is also a national foreign minister, and is therefore

47 Organisation for Security and Cooperation in Europe <http://www.osce.org > (last accessed 18 June 2001).

48 Michael Murray "The Language of Avoidance: How Human Rights Issues are Constrained by the Rhetoric of Non-Western Participants in the OSCE" (1997) 9 Int'l Legal Persp 227, 241.

49 Stephen R Ratner "Does International Law Matter in Preventing Ethnic Conflict?" (2000) 32 NYU J Int'l L \& Pol 591, 605.

50 Paul Martin "Regional Efforts at Preventative Measures: Four Case-Studies on the Development of Conflict-Prevention Capabilities" (1998) 30 NYU J Int'l L \& Pol. 881, 901.

51 Ratner, above, 616.

52 Ratner, above, 616. 
more likely to take political ramifications into account when making decisions. ${ }^{53}$ In the area of ethnic tensions, which as we have seen are a cause of many of today's conflicts, the OSCE has passed several declarations regarding minority rights which, although very general in nature, have served to alleviate many potential conflicts between governments and minorities. ${ }^{54}$

The OSCE has also been very successful in developing a new role for regional organisations under the United Nations Charter. It appeared to hear Boutros Boutros Ghali's call for the new Chapter VIII era, and has embraced it with vigour. Currently, the OSCE is the only regional organisation which is directly reporting to the Security Council on matters of international peace and security. ${ }^{55}$ The organisation also has observer status at the United Nations, and works closely with the various departments within the organisation. ${ }^{56}$ Furthermore, the OSCE recognises when the United Nations is better suited to deal with a particular situation, and takes steps to ensure that the two organisations are not working at cross-purposes. ${ }^{57}$ It therefore appears that, despite its limitations, the OSCE is an excellent model of a contemporary, adaptable conflict prevention organisation.

\section{The Association of South East Asian Nations}

The Association of South East Asian Nations (ASEAN) in many ways could not be more different from the OSCE. For a start, it is on a much smaller scale, with only ten member States. ${ }^{58}$ It also takes a very different approach to conflict prevention. However, from a Commonwealth perspective, it is useful to understand how ASEAN works, as three of the ten members of ASEAN are members of the Commonwealth. Also, if the Commonwealth wants to play a valid role as a conflict prevention body, it needs to fully understand the various approaches that regional and cultural arrangements in Asia take to dispute settlement.

ASEAN was established in 1967 by the ASEAN (or Bangkok) Declaration. At that time there were only five member States. ${ }^{59}$ This document contained three fundamental purposes for the organisation, one of which was "to promote regional peace and stability through abiding respect for justice and the rule of law in the relationship among countries of the region and adherence to the

53 Martin, above, 893.

54 Ratner, above, 682.

55 Christian Berger "OSCE and International Law" (1996) 24 Int'l J Legal Info 36, 38.

56 Berger, above, 38.

57 Ratner, above, 619.

58 Brunei Darussalam, Cambodia, Indonesia, Laos, Malaysia, Myanmar, Phillippines, Singapore, Thailand and Vietnam.

59 Association of South East Asian Nations $<$ http://www.asean.or.id $>$ (last accessed 22 June 2001) [ASEAN]. 
principles of the United Nations Charter". ${ }^{60}$ The other two aims were economic growth and collaboration on matters of common interest. Over the years, ASEAN gradually grew larger, and began to articulate in more detail their common interest concerns. Various treaties and agreements have been signed between the member States over the years on matters as diverse as free trade and nuclear non-proliferation.

Like the OSCE and the Commonwealth, ASEAN has a Secretariat, located in Jakarta, which helps to administer the work of the organisation. The organisation also has national secretariats in member States, and small offices in the capitals of their "dialogue partners". Another similarity with the previous two organisations is the importance of heads of government meetings. These occur every three years, though informal meetings take place annually. The heads of government determine the direction for the organisation, which is then followed up on by various meetings of ministers and specialists from the member States. ${ }^{61}$ What is most important to note about how ASEAN and its meetings work, however, is the strong emphasis on consensus and non-intervention. A striking example of this can be seen in the Treaty of Amity and Cooperation in South East Asia. ${ }^{62}$ The first three of the six fundamental principles of this treaty refer in some way to non-interference and state sovereignty. Obviously a consensus method of decision making is the only way in which the member States can protect their strong commitment to state sovereignty.

In the area of conflict prevention and resolution ASEAN works in various ways. The most important development was the formation of the ASEAN Regional Forum (ARF) in 1994. This body consists of the ten ASEAN members plus ten "dialogue partners" who include the United States, China, Russia and the European Union. ${ }^{63}$ This group meets annually to discuss regional security concerns. Along with the ARF, there are several agreements dealing with conflict-related issues. Most important is the Treaty of Amity and Cooperation in South East Asia, which specifies that any conflict between states parties will be dealt with in a peaceful way. ${ }^{64}$

Like the OSCE, ASEAN is not without its critics. Nearly all the criticisms stem from the rigid adherence by member States to the principle of State sovereignty. This can be seen, for example, as the reason for the failure of the organisation to create a dispute settlement mechanism within the

60 The ASEAN Declaration (Bangkok Declaration) < http://www.asean.or.id/history/leader67.htm> (last accessed 22 June 2001).

61 ASEAN, above.

62 Treaty of Amity and Cooperation in South East Asia $1976<$ http://www.asean.or.id/summit/amity76.htm> (last accessed 22 June 2001).

63 Members of the ARF include all ASEAN members plus Australia, Canada, China, the European Union, India, Japan, Democratic People's Republic of Korea, Mongolia, New Zealand, Papua New Guinea, Russian Federation and the United States.

64 Treaty of Amity and Cooperation in South East Asia 1976, above. 
ARF. ${ }^{65}$ The member States appear hesitant to be put in a position where a decision will be forced upon them against their will. It is also the reason why ASEAN has been criticised for being reticent with respect to human rights. ${ }^{66}$ Monitoring of human rights is obviously an activity which would erode domestic jurisdiction, and few of the ASEAN States are willing to let this happen. However, the possibility of setting up an Eminent Persons Group, somewhat similar to the OSCE's High Commissioner on National Minorities, which would go to trouble spots and establish dialogue, has been discussed. ${ }^{67}$

Noting the fact that the non-interference principle is likely to severely hamper the growth of ASEAN as a conflict resolution body, it must be said that the presence of ASEAN is still an extremely valuable development. Not only does it provide a neutral forum in which member States can discuss issues of concern, but it also allows a group of diverse nations to speak with one voice. ${ }^{68}$ It must be recognised also that ASEAN has been very successful at preventing conflict amongst its members, and has attempted to encourage a peaceful settlement of the South China Sea dispute. ${ }^{69}$ Although the sovereignty issue may hinder its progress, the establishment of dialogue and relationships between ten highly diverse nations can only be seen as a positive step.

It is clear, therefore, that we have well and truly entered the "Chapter VIII Era". Regional organisations are taking on increased responsibility with respect to conflict resolution, and are therefore relieving some of the United Nations' workload. The OSCE and ASEAN take very different approaches to conflict and are in many ways at different ends of the spectrum of regional organisation. However, in order to develop properly, the Commonwealth needs to take lessons from both. The issue of non-interference, which is so integral to ASEAN, will also be an issue for the Commonwealth. Furthermore, the Commonwealth can learn from the way in which the OSCE has taken steps to institutionalise its dispute resolution procedures. Before we go on to look specifically at what steps the Commonwealth could take to become a more effective conflict resolution body we must first look at the organisation's role in recent disputes, and how well it has adapted so far.

65 Yoshi Kodama "Asia-Pacific Region: APEC and ASEAN" (1995) 30 Int'l L 367, 368.

66 Li-Ann Thio "Implementing Human Rights in ASEAN Countries: Promises to Keep and Miles to Go Before I Sleep" 2 Yale Human Rts \& Dev L J 1, 2.

67 John Yukio Gotanda, "Regional Institutions in East Asia and the Pacific: Is the Time Ripe?" (1995) 8 AM Soc Int'1 L Proc 471, 478.

68 Sherry M Stephenson "ASEAN and the Multilateral Trading System" (1994) 25 Law \& Pol'y Int'l Bus 439, 439.

69 Paul Martin "Regional Efforts at Preventative Measures: Four Case-Studies on the Development of Conflict-Prevention Capabilities" (1998) 30 NYU J Int'l L \& Pol 881, 928. 


\section{RECENT INVOLVEMENT IN CONFLICT RESOLUTION}

In order to fully evaluate how well the Commonwealth works in the conflict resolution arena, and how well it has adapted to the changing face of conflict, we need to look at specific examples of conflicts in Commonwealth nations. We need to analyse what was done, what effect it had, and possibly what should have been done differently. The three conflicts I will look at are Sierra Leone, Sri Lanka, and the Solomon Islands. These three have been chosen as they are all very different types and scales of conflict, they are all in different regions and they have all drawn very different responses from the Commonwealth.

\section{A Sierra Leone}

\section{The conflict}

A civil war in Sierra Leone began in 1991, when government forces began to clash with the Revolutionary United Front (RUF). ${ }^{70}$ A year later President Momoh was ousted in a military coup and the country was not to see a democratically elected President until $1996 .{ }^{71}$ In the years in between, there were several foiled coup attempts. ${ }^{72}$ When Ahmed Tejan Kabbah was elected to power in 1996, as a result of international pressure to hold democratic elections and resolve the conflict with the RUF, his term did not last long. ${ }^{73}$ Again it was the military which staged the coup, with some RUF officers also involved. ${ }^{74}$

In response to the coup the United Nations Security Council passed Resolution 1132 which encouraged the Economic Community of West African States (ECOWAS) to continue with its attempts to negotiate a solution, which it had been doing since the conflict began. ${ }^{75}$ After these attempts to negotiate failed to produce any concrete benefits, ECOWAS made the decision to use force. ${ }^{76}$ An ECOWAS force, which worked under the auspices of the Economic Community of

70 Microsoft Encarta Online Encyclopedia "Sierra Leone" $2001<$ http://encarta.msn.co.uk $>$ (last accessed 2 November 2001).

71 Babafemi Akinrinade "International Humanitarian Law and the Conflict in Sierra Leone" (2001) 15 Notre Dame J L Ethics \& Pub Pol'y 391, 395.

72 Microsoft Encarta, above.

73 Cry Freetown "Modern History of Sierra Leone" <http://www.cryfreetown.org/90s.html $>$ (last accessed 2 November 2001)

74 Lee F Berger "State Practice Evidence of the Humanitarian Intervention Doctrine: The ECOWAS Intervention in Sierra Leone" 11 Ind Int'l \& Comp L Rev 605, 616.

75 United Nations "Security Council Resolution 1132 on the Situation in Sierra Leone" $<$ http://www.un.org/Docs/scres/1997/9726713E.htm> (last accessed 2 November 2001).

76 Berger, above, 622. 
West African States Cease-Fire Monitoring Group (ECOMOG), was successful in capturing Freetown and restoring Kabbah to power in 1998. ${ }^{77}$

Although the rebel forces were largely expelled from Freetown, their campaign of terror continued in other parts of Sierra Leone, with reports of atrocities common. ${ }^{78}$ In July 1999, Kabbah and the leader of the RUF, Foday Sankoh, signed the Lome Peace Accord, following intense pressure from ECOWAS and other States to negotiate an end to the conflict. ${ }^{79}$ In order to ensure the effectiveness of this agreement, the United Nations established the United Nations Assistance Mission in Sierra Leone (UNAMSIL) to replace the United Nations Observer Mission which had been in place since $1998 .^{80}$ The Lome Accord collapsed less than a year after its signing, and the RUF began to take United Nations peacekeepers as hostages. ${ }^{81}$ The size of the United Nations force in Sierra Leone has continued to expand. ${ }^{82}$ Tensions continue to fester throughout the country, especially in the diamond-mining regions, where conflicts and human rights violations are still reported. ${ }^{83}$

\section{Commonwealth response}

The first direct action from the Commonwealth to the conflict was to suspend Sierra Leone from the organisation. ${ }^{84}$ Suspension is a tool used by the Commonwealth to bring member States into line with its principles. Pakistan is currently suspended from meetings of the Commonwealth, but not from the organisation itself. ${ }^{85}$ Nigeria has also been suspended in the past. ${ }^{86}$ Democratic government is one of the basic Commonwealth principles, therefore when Sierra Leone's elected president was removed from power, suspension was an obvious reaction.

77 Jeremy Levitt "Humanitarian Intervention by Regional Actors in Internal Conflicts: The Cases of ECOWAS in Liberia and Sierra Leone" (1998) 12 Temp Int'l \& Comp LJ 333, 366.

78 Babafemi Akinrinade "International Humanitarian Law and the Conflict in Sierra Leone" (2001) 15 Notre Dame J L Ethics \& Pub Pol'y 391,432.

79 Akinrinade, above, 437.

80 Akinrinade, above, 445.

81 Microsoft Encarta Online Encyclopedia "Sierra Leone," 2001<http://encarta.msn.co.uk> (last accessed 2 November 2001).

82 BBC News "UN Condemns Callous Attack" 31 July $2001<$ http://news.bbc.co.uk/hi/english/world/ africa/newsid_1467000/1467412.stm > (last accessed 2 November 2001).

83 BBC News, above.

84 Kate Ford and Sunder Katwala Reinventing the Commonwealth (Foreign Policy Centre, London, 1999) 23.

85 Commonwealth Ministerial Action Group "Chairman's Presentation of the Commonwealth Ministerial Action Group on the Harare Declaration" <http://www.chogm99.org/> (last accessed 17 October 2001).

86 Ford and Katwala, above, 23. 
The Commonwealth Secretary-General has also been involved directly in the conflict. Chief Emeka Anyaoku, a Nigerian, was Commonwealth Secretary-General from 1990-1999. ${ }^{87}$ The Secretary-General made use of his "good offices" role at numerous times during the Sierra Leone conflict. During the period when Kabbah was in exile in Guinea, Anyaoku held talks both with Kabbah and with the RUF in an attempt to bring them to the negotiating table. ${ }^{88} \mathrm{He}$, with the assistance of United Nations officials playing much the same role, succeeded in this twice, resulting in the Abidjan and Lome Agreements. ${ }^{89}$ When the Lome Agreement and cease-fire were finally negotiated in 1999, Anyaoku continued to meet with both parties in an attempt to ensure that the terms of the agreement were adhered to. ${ }^{90}$ The Commonwealth was a "moral guarantor" of both agreements. $^{91}$

The Commonwealth Ministerial Action Group (CMAG) has also been concerned with the situation in Sierra Leone and the nation has been on its agenda since the group's inception. ${ }^{92}$ CMAG has carefully monitored the situation and has also dispatched observer missions to Sierra Leone to find out precisely what was going on. ${ }^{93}$ Reports made by CMAG have been discussed at CHOGMs and have therefore greatly affected the stance the Commonwealth has taken towards the Sierra Leone situation. In September 2001, CMAG recommended that the Sierra Leone situation be withdrawn from its agenda, but maintained that the Secretary-General should continue to monitor the conflict. ${ }^{94}$

87 United Nations and Commonwealth Division, Ministry of Foreign Affairs and Trade "The Commonwealth Secretary-General Election Durban '99', CHOGM 1999 Press Kit.

88 The Commonwealth "Commonwealth Secretary-General Welcomes Sierra Leone Peace Move" $<$ http://www.thecommonwealth.org/dynamic/ViewAPress_search.asp?ID=216> (last accessed 7 November 2001)

89 Jeremy Levitt "Humanitarian Intervention by Regional Actors in Internal Conflicts: The Cases of ECOWAS in Liberia and Sierra Leone" (1998) 12 Temp Int'l \& Comp L J 333,365.

90 "Commonwealth Secretary-General Welcomes Sierra Leone Peace Move", above.

91 Commonwealth Ministerial Action Group "Chairman's Presentation of the Commonwealth Ministerial Action Group on the Harare Declaration" <http://www.chogm99.org/> (last accessed 17 October 2001).

92 The Commonwealth "The Commonwealth: In Pursuit of the Millbrook Action Plan: The Report of the Commonwealth Secretary-General 1997" <http:/www.thecommonwealth.org/dynamic/ViewAPress_ search.asp? ID=333> (last accessed 7 November 2001).

93 Commonwealth Ministerial Action Group, above.

94 The Commonwealth "Sixteenth Meeting Of The Commonwealth Ministerial Action Group On The Harare Declaration (CMAG) Marlborough House, 3-4 September 2001" <http://www.thecommonwealth.org/ dynamic/ViewAPress_search.asp?ID=317> (last accessed 7 November 2001). 
The Commonwealth has also been very involved in reconstruction efforts in Sierra Leone, which it sees as necessary in order for the democratic government to keep control. ${ }^{95}$ In 1998, a special police task force was dispatched to the nation, consisting of seven senior police officers from various Commonwealth countries. ${ }^{96}$ Their intention was to work with the Sierra Leone police force, and with other international agencies, to get the police force back on its feet and running smoothly. The United Kingdom also provided extra funds and resources to retrain the police force. ${ }^{97}$ In 1999 , Kabbah appointed the British leader of this group, Keith Biddle, as the head of the Sierra Leonean police force, in an attempt to root out corruption. ${ }^{98}$

\section{Analysis of Commonwealth role}

The involvement of the Commonwealth in Sierra Leone has been useful in demonstrating both the benefits and drawbacks of the way the organisation works. For a start, the Sierra Leone conflict illustrated the Commonwealth's ability to take a regional approach to issues of concern. Although there are currently numerous Western States involved in the United Nations force in Sierra Leone, at first the Commonwealth appeared to be tapping merely those from African States as its representatives. Also, Nigeria and Ghana, both Commonwealth States, took a lead role in the ECOWAS intervention. Although it is important to recognise that these are Commonwealth States intervening in a Commonwealth conflict, it must be noted that the individual states no doubt were, to some extent at least, serving their own interests. Furthermore, we must remember that the Secretary-General until 1999, Chief Emeka Anyaoku, is a Nigerian. Two inferences can be taken from this fact. First, it could be said that Anyaoku was particularly concerned with resolving the conflict as it threatened the stability of his home State, being a neighbour of Sierra Leone. Secondly, it is very likely that Anyaoku's nationality meant he was more likely to be able to understand the roots of the conflict and also communicate more effectively with the key players.

The Commonwealth's role in the conflict also illustrated how it can be effective as a behind the scenes player. The organisation has nothing like the resources or mandate of the United Nations to get actively involved in the resolution of the conflict. However, the mere presence of the organisation and its representatives, especially Anyaoku, and the support given to the ECOWAS and

95 The Commonwealth "Commonwealth Secretary-General Welcomes Cease-fire in Sierra Leone" $<$ http://www.thecommonwealth.org/dynamic/ViewAPress_search.asp?ID=246> (last accessed 7 November 2001).

96 The Commonwealth "Twelfth Meeting of the Commonwealth Ministerial Action Group on the Harare Declaration (CMAG) New York, 30 September - 1 October 1999" <http://www.thecommonwealth.org/ dynamic/ViewAPress_search.asp?ID=209> (last accessed 28 November 2001).

97 Human Rights Watch "Sierra Leone: Human Rights Developments" <http://www.hrw.org/wr2k/ Africa-09.htm> (last accessed 6 November 2001).

98 BBC News "British Clean-up for Sierra Leone Police" <http://news.bbc.co.uk/hi/english/world/ africa/newsid_536000/536233.stm> (last accessed 6 November 2001). 
United Nations operations, should not be underestimated. Furthermore, the "good offices" role of the Secretary-General was influential in bringing the rival parties to the negotiating table twice. Although both of the agreements made at these negotiations eventually failed to last, the establishment of dialogue between the RUF and the official government was an important development.

The Sierra Leone conflict also illustrated some of the limits on Commonwealth action. First, the Commonwealth at no stage took a lead role in resolving the conflict, leaving this to organisations like ECOWAS and the United Nations. The conflict was on such a large scale, and so brutal, that it is unlikely that the organisation could have coped on its own. Secondly, the conflict showed that the Commonwealth is still battling to dispel opinions that it is merely a tool of the British government, and also has problems ensuring that its member States are acting in the interests of the organisation and not purely out of self-interest. These problems were particularly evident during the Sandline controversy, when a British security firm was accused of sending a shipment of arms to Sierra Leone, with the knowledge of the British government and in violation of a United Nations arms embargo. ${ }^{99}$

A final question which must be answered is what the Sierra Leone example can tell us about how well the Commonwealth has adapted its conflict resolution mechanisms to the new type of conflict. In many ways this civil war encapsulates this new breed of war: it is largely internal, it has transnational implications, and there is a large amount of civilian involvement and guerilla warfare. What makes the Sierra Leone conflict different from many others taking place today, however, is the lack of ethnic or religious causes. Those who deposed Kabbah did so, ostensibly, as a result of frustration due to low wages and poor conditions. ${ }^{100}$ The RUF's motives, however, are less clear, though it is likely that the desire for the diamond revenue, which is the country's primary resource, has a major part to play. ${ }^{101}$

The involvement of CMAG is probably the key indication that the Commonwealth has adapted well to this kind of conflict. It has taken a key role in the Sierra Leone conflict, from monitoring to observer missions to recommendations to the Secretary-General. The fact that CMAG has become actively involved in Sierra Leone, despite the many problems and controversies which the conflict has produced, is testimony to the Commonwealth's commitment to dealing with conflict head-on. However, it must also be noted that the Commonwealth has not, as of yet, been successful in restoring peace, hence the conflict will require the Commonwealth's continued attention.

99 CNN News "British Minister Denies Wrongdoing in Sierra Leone" <http://www8.cnn.com/ WORLD/africa/9805/12/brit.sierra.leone/> (last accessed 2 November 2001).

100 Lee F Berger "State Practice Evidence of the Humanitarian Intervention Doctrine: The ECOWAS Intervention in Sierra Leone" 11 Ind Int'l \& Comp L Rev 605, 616.

101 Babafemi Akinrinade "International Humanitarian Law and the Conflict in Sierra Leone" (2001) 15 Notre Dame J L Ethics \& Pub Pol'y 391, 397. 


\section{B Solomon Islands}

\section{The conflict}

The conflict in the Solomon Islands in many respects could not be more different from that in Sierra Leone. For a start, it lasted for a much shorter time, was on an infinitely smaller scale, and was to no extent as brutal as that in Sierra Leone. Unlike Sierra Leone, it would be easy to say that the conflict in the Solomons is an ethnic, or at least a tribal, conflict. Although $95 \%$ of the population is Melanesian, there are huge regional and linguistic differences which have created tension in the tiny Pacific nation. ${ }^{102}$ The problems are largely between residents of the island of Guadalcanal, and those from the nearby island of Malaita. However, it would be wrong to say that cultural differences alone are the cause of the dispute.

The capital of the Solomon Islands, Honiara, is situated on the island of Guadalcanal. The recent conflict stemmed mainly from the fact that large numbers of people from Malaita had come to Honiara, both before and after independence, and had taken what many local residents saw as a disproportionate amount of the jobs and land available on Guadalcanal. ${ }^{103}$ It has been said that "competition for resources typically lies at the heart of ethnic conflict", ${ }^{104}$ and the Solomons situation could therefore be said to be a "typical" ethnic conflict. As a result of this resentment a group called the Isatabu Freedom Movement (IFM) evolved to protect the rights and land of the original residents of Guadalcanal. ${ }^{105}$ In 1998, the IFM began evicting Malaitans, and forcing them off their land, and sometimes back to Malaita. ${ }^{106}$ In response to these actions, a rival group called the Malaita Eagles Force (MEF) was formed. ${ }^{107}$ The MEF, claiming to represent the minority Mataitan population on Guadalcanal, was involved in confrontations with the Solomon Island police

102 The Guardian "Second South-Pacific Coup" < http://www.guardian.co.uk/solomon/article/ 0,2763,329207,00.html> (last accessed 7 November 2001).

103 National Review Online "Solomon Says: The Madness of Civilian Disarmament in the South Pacific" $<$ http://www.nationalreview.com/kopel/kopel112700.shtml $>$ (last accessed 7 November 2001).

104 David A Lake and Donald Rothchild "Spreading Fear: The Genesis of Transnational Ethnic Conflict" in David A Lake and Donald Rothchild The International Spread of Ethnic Conflict (Princeton University Press, Princeton, 1998) 9.

105 BBC News "Solomons Celebrates Peace Deal" <http://news.bbc.co.uk/hi/english/world/asiapacific/newsid_980000/980937.stm> (last accessed 7 November 2001).

106 World Socialist Website "Solomon Islands Coup Sets Stage for Civil War" $<$ http://www.wsws.org/articles/2000/jun2000/sol-j07.shtml > (last accessed 7 November 2001).

107 "Second South-Pacific Coup", above. 
and the IFM in the ensuing months. ${ }^{108}$ It is estimated that around sixty people were killed during the fighting. 109

The conflict hit the world stage in June 2000 when the MEF took control of Honiara and demanded the resignation of the Prime Minister, Bartholomew Ulufa'alu. ${ }^{110}$ The fact that this action took place just three weeks after the George Speight-led coup in nearby Fiji was seen by many as no coincidence. ${ }^{111}$ The leader of the MEF, however, maintained that the actions in the Solomons did not constitute a coup, and were merely a demand that a new Prime Minister be elected who would pay more attention to ethnic concerns. ${ }^{112}$ Representatives from neighbouring States, including New Zealand and Australia, were quick to become involved and, through a largely Commonwealth initiative, saw the signing of a peace agreement in Townsville, Australia in October 2000. ${ }^{113}$ Unlike the peace agreements in Sierra Leone, this agreement has been largely successful in bringing peace to the Solomons.

\section{Commonwealth response}

The Commonwealth has taken a much more "hands-on" role in the resolution of the conflict in the Solomon Islands than it did in Sierra Leone. This can be explained by the fact that it was one of the few organisations which really had any kind of responsibility, or mandate, to intervene. ${ }^{114}$ Arguably, the United Nations could have done so, and probably would have had the Commonwealth not become involved. However, there is no regional organisation in the South Pacific area which could have taken on an ECOWAS-type role. The Commonwealth therefore took on an active and visible role in the Solomon Islands conflict.

When the conflict first began in 1998, the Secretary-General of the Commonwealth sent a special envoy to the Solomons to begin negotiations with the rebel factions. ${ }^{115}$ Somewhat ironically

108 "Second South-Pacific Coup", above.

109 BBC News "Commonwealth Threatens Solomons" <http://news.bbc.co.uk/hi/english/world/asia-pacific/ newsid_779000/779175.stm> (last accessed 7 November 2001).

110 "Commonwealth Threatens Solomons", above.

111 "Second South-Pacific Coup", above.

112 "Commonwealth Threatens Solomons", above.

113 The Solomon Islands Ministry of Commerce "The Townsville Peace Accord" $<$ http://www.commerce.gov.sb/Others/Peace\%20agreement.htm> (last accessed 7 November 2001).

114 In respect of mandate, CMAG could base their intervention on the fact that they are charged with protecting good governance and human rights, both of which were put at risk by the Solomons conflict.

115 The Commonwealth "Commonwealth Secretary-General Dispatches Special Envoy to Solomon Islands" $<$ http://www.thecommonwealth.org/dynamic/ViewAPress_search.asp?ID=236> (last accessed 7 November 2001). 
the person chosen for this role was the Honourable Major-General Sitiveni L Rabuka, who was involved in the first coup in Fiji in 1987. However, the Secretary-General chose Rabuka because of "his considerable experience and depth of understanding of island affairs". 116 The choosing of Rabuka, a person who indeed did have a much deeper understanding of the conflict than many of his counterparts, immediately paid off. Rabuka managed to negotiate successfully with the MEF and the IFM and a peace deal was hammered out in $1999 .{ }^{117}$

Despite monitoring by Commonwealth States in the region, the Honiara Peace Accord slowly unraveled, with its failure finally illustrated by the taking of Honiara by the MEF. In response to this action the Commonwealth sent a delegation including the New Zealand and Australian foreign ministers. ${ }^{118}$ The delegation met with the ousted Prime Minister, as well as with members of the MEF and managed to secure a two-week truce. ${ }^{119}$ The delegation was sent under the auspices of CMAG, which had been paying close attention to the situation in the Solomons. ${ }^{120}$ In response to the coup, as well as sending the delegation, suspension was threatened. ${ }^{121}$

This step did not need to be taken, however, as the Townsville Peace Agreement was brokered in October 2001, as a result of negotiations between the Commonwealth delegation and the parties, and also partly due to the pressure from CMAG. ${ }^{122}$ The agreement was concerned mainly with disarmament and investigations into disputes over land ownership. ${ }^{123}$ In order to ensure that the agreement was adhered to, especially those provisions relating to disarmament, it was stipulated that unarmed peacekeepers from Australia and New Zealand would travel to the Solomons to oversee the

116 "Commonwealth Secretary-General Dispatches Special Envoy to Solomon Islands", above.

117 CHOGM 1999 "Diplomacy and Conflict Resolution" < http://www.chogm99.org/> (last accessed 17 October 2001).

118 BBC News "Hope for Solomons Peace" <http://news.bbc.co.uk/hi/english/world/asia-pacific/ newsid_784000/784970.stm> (last accessed 7 November 2001).

119 "Hope for Solomons Peace", above.

120 The Commonwealth "Commonwealth News And Information Service Issue 5, 21 September 2000" $<$ http://www.thecommonwealth.org/dynamic/ViewAPress_search.asp?ID=151> (last accessed 8 November 2001).

121 BBC News "Commonwealth Threatens Solomons" <http://news.bbc.co.uk/hi/english/world/asia-pacific/ newsid_779000/779175.stm> (last accessed 9 November 2001).

122 BBC News "Solomons Celebrates Peace Deal" <http://news.bbc.co.uk/hi/english/world/asia-pacific/ newsid_980000/980937.stm> (last accessed 9 November 2001).

123 The Solomon Islands Ministry of Commerce "The Townsville Peace Accord" $<$ http://www.commerce.gov.sb/Others/Peace\%20agreement.htm> (last accessed 7 November 2001). 
weapons handover. ${ }^{124}$ As at the time of writing, the International Peace Monitoring Team is still present in the Solomons. ${ }^{125}$

\section{Analysis of Commonwealth Role}

Despite the massive differences between the conflicts in Sierra Leone and the Solomons, and the Commonwealth reaction to them, there are some notable similarities. For a start, the Solomons conflict again showed the Commonwealth's willingness to work regionally. As in Sierra Leone, respected representatives from nearby States were sent in to attempt to broker an agreement. Also, in the Solomons there was no regional organisation to take control, hence the Commonwealth, and its representatives, took a more active role.

Related to this point, the Solomons conflict showed how the Commonwealth can cope with problems on its own, without the input of larger organisations like the United Nations. Obviously the real test will come if the Commonwealth has to deal with a more brutal and widespread conflict, like that in Sierra Leone. However, the organisation has clearly proven its conflict resolution abilities in the Solomons. Through careful negotiating and subtle pressure, the Commonwealth managed to prevent the conflict from blowing up into something beyond its control. The fact that the matter was kept off the United Nations agenda, and that the Commonwealth was able to negotiate a solution - without resort to force and despite the fact that it was already occupied with problems in Fiji - should be seen as a major step for the organisation, and as very reassuring for the international community.

Again we must look at the question of adaptability. The conflict in the Solomons was largely one of civilian versus civilian, complicated further by the fact that there was no official army to intervene and prevent things from escalating out of control. The fact that the Commonwealth was able to do this, without deploying huge numbers of peacekeepers, bodes well for the future. As we have seen, many Asian States are more in favour of preventative diplomacy than active conflict resolution. The Commonwealth's role in the Solomons would more than likely be acceptable, therefore, to its Asian members. After all, the role played in the Solomons, although it may have been more visible than in Sierra Leone, was ultimately still a behind the scenes one.

\section{Sri Lanka}

\section{The conflict}

The conflict in the former British colony of Ceylon (now Sri Lanka) began brewing when independence was granted in 1948, though the problems underlying it had been festering for much

124 "Solomons Celebrates Peace Deal", above.

$125 \mathrm{New}$ Zealand Army "Solomon Islands" < http://www.army.mil.nz/nzarmy/grids/a_grid_map.asp?id $=148 \&$ area $=9>($ last accessed 26 September 2002). 
longer. Like the Solomons, it is an ethnic conflict. The two main ethnic groups in Sri Lanka are the Sinhalese, a predominately Buddhist group who make up $74 \%$ of the population, and the Tamils, who make up $18 \%$ and are mostly Hindu. ${ }^{126}$ The Tamils dominate the northern and eastern areas of Sri Lanka. ${ }^{127}$

Tensions between the two groups led to the outbreak of civil war in 1983. The main parties involved are the central government, dominated by Sinhalese, and the Liberation Tigers of Talim Eelam (LTTE), who are advocating secession and the creation of a new Tamil state. ${ }^{128}$ From the beginning, the conflict has had transnational implications with the LTTE having a support base which stretches from the Indian state of Tamil Nadu, to major cities including London and Auckland. ${ }^{129}$ Also, India has taken a leading role in attempting to broker a solution in Sri Lanka, and in 1987 it signed the Indo-Sri Lankan Accord with the Sri Lankan government, which called for a cease-fire and the disarmament of rebel forces. ${ }^{130}$ When this agreement collapsed, largely due to the lack of involvement by Tamils in the negotiating process, the Indian government took a more active role and sent in a peacekeeping force. By February 1988, India had committed 50,000 soldiers to the operation, only to withdraw them in 1990, having made no real progress. ${ }^{131}$ The Tamils, whom the Indian peacekeepers were ostensibly there to protect, did not welcome the intervention, and continued with their armed struggle. ${ }^{132}$

The years following were characterised by continuing violent confrontations between the LTTE and the government armed forces. Another cease-fire was agreed on in 1994 but collapsed less than a year later. ${ }^{133}$ In 1999, the United Nations estimated that there were 12,000 missing persons in Sri Lanka (second only to Iraq), and the conflict has resulted in approximately 60,000 deaths. ${ }^{134}$ At the

126 Central Intelligence Agency "Factbook - Sri Lanka" <http://www.cia.gov/cia/publications/ factbook/> (last accessed 9 November 2001).

127 David M Rothenberg "Negotiation and Dispute Resolution in the Sri Lankan Context: Lessons from the 1994-1995 Peace Talks" (1998) 22 Fordham Int'l L J 505,511.

128 Microsoft Encarta Online Encyclopedia 2001 "Sri Lanka" <http://encarta.msn.co.uk> (last accessed 9 November 2001).

129 Douglas M Johnston "Religion and Conflict Resolution" (1992) 67 Notre Dame L Rev 1433, 1438.

130 Rothenberg, above, 522.

131 Johnston, above, 1439.

132 Johnston, above, 1439

133 Microsoft Encarta Online Encyclopedia 2001 "Sri Lanka" <http://encarta.msn.co.uk> (last accessed 9 November 2001).

134 Peter Chalk "The Liberation Tigers of Tamil Eelam Insurgency in Sri Lanka" in Rajat Ganguly and Ian Macduff (eds) Ethnic Conflict and Secessionism in Asia (Sage Publications, New Delhi, 2003) 23. 
time of writing, the ceasefire brokered by the Norwegian government has held for a year notwithstanding several violent confrontations.

\section{Commonwealth response}

Of the three conflicts discussed, it is Sri Lanka which the Commonwealth has had the least to do with. The reasons for this will be discussed shortly, but, at its most basic, it comes down to the question of consent mentioned earlier. The Sri Lankan government has been reluctant for the Commonwealth to become involved, hence its ability to intervene is impaired. As in Sierra Leone and the Solomons, however, Commonwealth States have been involved. It could be said, however, that India's reasons for intervening are more for historical, religious, and strategic reasons than from any sense of wanting to protect another Commonwealth country from falling apart.

The Commonwealth has been involved to a limited extent, with the Secretary-General meeting with the Sri Lankan President in 1998 and offering the services of the Commonwealth to mediate. ${ }^{135}$ The Commonwealth Secretary-General refused to comment on whether peace talks would go ahead, and if so, what role the Commonwealth would play in them. However, in an interview with the BBC in 1999, Sri Lankan President Chandrika Kumaratunga revealed that Secretary-General Emeka Anyaoku had been involved in negotiations with the government and the LTTE since 1997. ${ }^{136}$ However, she also stated that the LTTE had stopped meeting with Anyaoku after eighteen months of talks had failed to make any concrete progress. ${ }^{137}$

However, aside from this, the Commonwealth has been noticeably quiet on the issue of Sri Lanka. That is not to say that it is being ignored, as it has been frequently referred to as an illustration of the "new" type of conflict which the Commonwealth is allegedly so well prepared to deal with. ${ }^{138}$ Meetings of the Commonwealth have also been a breeding ground for demonstrations on the Sri Lankan issue, with the Tamil protest at the Edinburgh CHOGM in 1997 being the most widely reported. ${ }^{139}$ The British government also agreed in 2001 to lend support and assistance to the

135 BBC News "Commonwealth Chief Says the Time has Come for Peace Talks in Sri Lanka" $<$ http://news6.thdo.bbc.co.uk/hi/english/world/s/w_asia/newsid_80000/80952.stm> (last accessed 28 November 2001).

136 BBC News "Extracts from President Kumaratunga's Interview" <http://news.bbc.co.uk/ hi/english/world/south_asia/newsid_583000/583120.stm> (last accessed 10 November 2001).

137 "Extracts from President Kumaratunga's Interview", above.

138 The Commonwealth "The Modern Commonwealth: Celebrating the Golden Jubilee" $<$ http://www.thecommonwealth.org/dynamic/ViewAPress_search.asp?ID=107> (last accessed 10 November 2001).

139 Tamil Canadian "Tamils Demonstrate at CHOGM" <http://www.tamilcanadian.com/eelam/hrights/ html/article/SU980604083043N107.html> (last accessed 10 November 2001). 
Norwegian peace initiative, and it is likely that the Commonwealth is playing much the same role. ${ }^{140}$

\section{Analysis of Commonwealth Role}

It would be easy to jump to criticism of the Commonwealth's apparent lack of response to the continuing civil unrest in Sri Lanka. One would assume that the organisation would be immensely concerned that one of its member nations has been at war for nearly twenty years, with more than 60,000 of its citizens killed. However, the CMAG, so swift to react to conflicts in Sierra Leone and the Solomons, has been disturbingly silent on the matter. The Secretary-General has played a role but has been reluctant to reveal what that role is or the extent to which he has influenced events.

It is arguable, however, that despite the appearance of apathy, the Commonwealth is actually intensely worried about the situation in Sri Lanka. The organisation is restricted in what action it can take, however, as the Sri Lankan situation poses some unique and complex problems. First, there is the issue of consent. Both the Harare and Singapore Declarations begin by stating that every Commonwealth State is independent and sovereign, and is responsible for its own policies. The focus on consensus and cooperation which permeates all Commonwealth work shows the reluctance of the organisation to become involved where it is not wanted. In Sri Lanka, the issue of consent has been decidedly unclear, and things have been complicated by the fact that it would be difficult to pick which side to back. Having guaranteed that the organisation would stay out of the domestic affairs of member States, the Commonwealth to an extent has its hands tied.

This position is complicated further by the fact that the conflict is essentially a secessionist struggle. Secession is one of the most controversial minefields in international law today, and the Commonwealth has come head to head with it in Sri Lanka. The Singapore Declaration states that the organisation will do its best to ensure that the right of self-determination is advanced. However, when this document was drafted, self-determination was applicable solely to those groups still under colonial domination who were struggling for independence. As we have seen, however, independence has led to struggles for power in numerous former colonial nations, and in Sri Lanka has led to a secessionist struggle. Has the adaptable Commonwealth adapted enough to deal with this issue? The lack of involvement in Sri Lanka would appear to suggest that it has not.

However, three points must be noted in the Commonwealth's defence. First, it is not the only organisation to struggle with the secession issue. It is very much a developing area and few countries or organisations are ready to recognise the right of secession yet. Secondly, the international community as a whole has failed to respond adequately to the conflict, and has been

140 BBC News "UK to help Sri Lanka Peace Push" < http://news.bbc.co.uk/hi/english/world/south_asia/ newsid_1046000/1046695.stm >(last accessed 10 November 2001). 
accused of acting irresponsibly. ${ }^{141}$ One writer has concluded that Security Council intervention in any Asian conflict is unlikely as "they are not salient to the interests of the Permanent Five". ${ }^{142}$ Thirdly, the Commonwealth has probably played the most appropriate role possible considering the nature of the conflict. As was discussed earlier, attempts at mediation are often more successful when conducted out of the media spotlight. Furthermore, this more low-key approach is in line with the traditional Asian method of resolving conflicts. This aspect of the Commonwealth intervention should be applauded, although the fact remains that the issue of secession has yet to be properly dealt with.

The analysis of the Commonwealth's role in these three unique conflicts has raised some important points. On the positive side, the creation of CMAG and its role as monitoring body has been a major step forward, both on a symbolic and practical level. The good offices role of the Secretary-General and his special envoys has also been largely successful, and has no doubt enhanced the reputation of the organisation. The three conflicts have also illustrated some of the limits on Commonwealth action. Most important is the issue of consent, which can prevent the organisation from playing a role where its mediation may be desperately needed. Also of concern is the Commonwealth's ability to react to conflicts which may not be as clear-cut as the ousting of a democratically elected leader. The existence of internal conflicts will of course pose new problems for the Commonwealth to the extent that consensus as to which side to support is increasingly difficult to achieve. The next chapter will examine various proposals to change the way the Commonwealth responds to conflict, and recommend ways in which it can overcome the problems which currently face it.

\section{ADAPTING THE COMMONWEALTH}

States and organisations should always be concerned with how they can improve their methods of resolving conflict, as the existence of disputes not only threatens human lives, but can also impact negatively on democratic government and economies. As an organisation, the Commonwealth has recognised the importance of resolving conflicts and has developed specific methods which it uses. As Part IV has shown, the Commonwealth has been reasonably successful in adapting to the new kinds of conflict which have become prevalent. It has done so not by making major changes, and not by trying to emulate the United Nations, but simply by adapting procedures which have come to be accepted by member States. It is with this in mind that the following aspects of Commonwealth conflict resolution procedures are discussed, and some proposals for change made.

141 Peter Chalk "The Liberation Tigers of Tamil Eelam Insurgency in Sri Lanka" in Rajat Ganguly and Ian Macduff (eds) Ethnic Conflict and Secessionism in Asia (Sage Publications, New Delhi, 2003) 128.

142 David Carment "Secessionist Ethnic Conflict in South and Southeast Asia: A Comparative Perspective" in Ganguly and Macduff, above, 23. 


\section{A Regionalism}

As we saw in Part III, regional organisations have risen to prominence in recent years. Not only have they proliferated, but transregional organisations, including the Commonwealth, have embraced regional approaches to conflict resolution. As we saw in both the Solomons and Sierra Leone, the Commonwealth has worked through existing regional organisations, or by using leaders with knowledge of the region. In the Solomons especially, this was a successful method. It would therefore make sense for the Commonwealth to continue to expand its ability to work on a regional level.

One way to ensure that the Commonwealth works effectively on a regional level would be to set up regional secretariats in each of the main Commonwealth regions. These offices could be quite small, and may vary in size depending on the population of the region and also the existence of another regional organisation in the area. The regional secretariats would be responsible for coordinating interaction with member States and regional organisations and also for monitoring potential conflict situations. The idea of delegating authority to a regional level is not unknown to the Commonwealth, with the Commonwealth Youth Programme being one section of the organisation which carries out its work on a regional level. ${ }^{143}$

The idea of regional secretariats, if implemented effectively, would provide numerous benefits. First, from a public relations perspective, a regional secretariat system would help the Commonwealth to move away from the image of the organisation as "British". A Foreign Policy Centre report, published in 1999, suggested that there was a need to equalise ownership of the Commonwealth, and thought this could be done by relocating the Secretariat, possibly to South Asia. ${ }^{144}$ I would suggest that having regional secretariats would produce the same result. Secondly, regional Commonwealth offices would allow for quicker and more culturally sensitive action which could, potentially, have the support of the entire region. Writers have consistently emphasised the importance of using traditional cultural processes to resolve conflict, ${ }^{145}$ and by having regional Commonwealth representatives it is more likely that such processes would be understood and used. Thirdly, this approach could allow regions to react to conflicts in their neighbourhood in a manner which they see fit, and would therefore allow for the differing regional approaches to conflict resolution to co-exist within the Commonwealth. Related to this is the fact that, in some regions at least, the role of the regional secretariat may consist solely of maintaining communication and cooperation with strong regional organisations which exist, such as the OAU. Obviously the

143 Commonwealth Youth Programme <http://www.cypyouth.org/About.htm> (last accessed 26 November 2001).

144 Kate Ford and Sunder Katwala Reinventing the Commonwealth (The Foreign Policy Centre, London, 1999) 55.

145 Don Mackay "New Zealand, The United Nations and Conflict Resolution" in Peter Greener (ed) Turning the Tide: A New Approach to Conflict Resolution (Auckland University of Technology, Auckland, 2001) 6. 
Secretary-General and CMAG would still be on hand to intervene should regional efforts prove fruitless.

However, there are several problems that would need to be addressed before the regional secretariat idea could be turned into reality. First, the idea would need to be supported by all member States, which may not be an easy task. Secondly, it would need to be shown that the establishment of regional offices would be a viable use of Commonwealth funds, as they would be expensive to set up and run. Finally, there is a risk that having Commonwealth powers delegated to a regional level may encourage a splintering of the organisation into regional factions. Although this is a valid concern, I would suggest that as long as guidelines are established and regular contact is maintained between the regional secretariats and the existing Secretariat, this problem could be avoided. Overall, the idea of regional offices is one which the Commonwealth should at least consider as an option.

\section{B The Commonwealth Ministerial Action Group (CMAG)}

The establishment of CMAG was a major change in tack for the Commonwealth. Not only did it indicate a more institutionalised approach to conflict resolution, but it also indicated that the Commonwealth had accepted that it could no longer afford to take a completely ad hoc approach to conflicts, good governance and human rights. However, as a relatively new body, CMAG is still learning how it can work best, and has to a large extent been fairly cautious in how it wields its power. In certain situations, CMAG has been able to act immediately and decisively, the reaction to the coup in Pakistan being one example. However, in 1999 the Foreign Policy Centre noted two key problems with CMAG. First, the body only seemed willing to deal with clear examples of democratic governments being toppled, usually in the cases of military dictatorships. ${ }^{146}$ The second problem was that there had yet to be a South Asian representative on CMAG. ${ }^{147}$ The extent of this problem becomes clearer when one recognises that $80 \%$ of the Commonwealth's population comes from that region. ${ }^{148}$ The latter issue was addressed at the 1999 Durban CHOGM, when a representative from Bangladesh was appointed to CMAG. ${ }^{149}$

With respect to the first problem, there appears to be a need for CMAG to broaden its approach. The mandate itself does not appear to be a problem, as the Millbrook Commonwealth Action Programme states that CMAG can concern itself with any infringement of the Harare

146 Ford and Katwala, above, 27.

147 Ford and Katwala, above, 84.

148 Ford and Katwala, above, 84.

149 CHOGM 1999 "The Durban Communique" <http://www.chogm99.org/> (last accessed 17 October 2001). 
Declaration. ${ }^{150}$ However, the Programme also put a special focus on the overthrow of democratic government, and CMAG appears, at this point at least, to have no desire to deal with any other infringements of the Declaration. In Sri Lanka, for example, human rights abuses have been extensively reported, yet CMAG has played no role. The reason for this lack of intervention is also probably the cause of CMAG's thus far cautious approach to its mandate. It is the problem of sovereignty. There is no easy way to solve this problem, and it will take much discussion and compromise in order to ensure that CMAG can take a wider approach to its mandate. This problem could also partially be overcome if CMAG does take the advice of the Foreign Policy Centre and ensure that it has a South Asian representative at all times. Although it was obviously a step forward when CMAG took on a member from Bangladesh, it is concerning that it took four years for a South Asian representative to be nominated. One way to ensure fair allocation of seats and equal participation would be to have each regional secretariat nominate a representative for CMAG.

Another idea which, if implemented, would likely fall under the auspices of CMAG, is that of a Commonwealth peacekeeping force. It has been debated for years, with valid arguments on both sides. As mentioned earlier, there is general agreement that the Commonwealth should not try to emulate the United Nations, and the United Nations is traditionally the primary peacekeeping coordinator. However, we have also seen that regional organisations are taking on increased responsibility for both peacemaking and peacekeeping, as the United Nations struggles to keep up with the growing number of internal conflicts. Should the Commonwealth decide to become involved in peacekeeping missions directly this could be seen as a new era for the organisation, and possibly as a move away from the behind the scenes conflict prevention it has traditionally engaged in. The organisation would have to decide to what it extent it would act as a coordinator of peacekeeping missions and what kind of interventions are within its mandate. These are ultimately questions that should be considered by the Commonwealth itself, though on the basis of the foregoing discussion the following recommendations can be made.

First, there does not appear to be a need for the Commonwealth to organise a standing force, as even the United Nations does not have one and has coped reasonably well. However, it could be beneficial, in some regions at least, to have a Commonwealth umbrella for intervention by troops from Commonwealth States. Symbolically, if all the Commonwealth States in a particular region are involved in the intervention, or at the very least the decision to intervene, there is less chance of the intervention being seen as an action merely to protect the strategic interests of a particular State. On a practical level, there is more chance of an intervention being successful if it is organised by the Commonwealth rather than independent States. The Commonwealth has access to information from 54 States, and has contacts with numerous organisations, hence it is more likely to be able to access

150 The Commonwealth "The Millbrook Commonwealth Action Programme on the Harare Declaration, 1995" $<\mathrm{http}: / /$ www.thecommonwealth.org/whoweare/declarations/millbrook.html $>$ (last accessed 12 November 2001). 
relevant information about the conflict, and what needs to be done to resolve it. Furthermore, it has been noted that in recent years peacekeeping forces, even those with some support from the UN, are often made up of soldiers from developing states who lack sufficient equipment and training. ${ }^{151} \mathrm{By}$ ensuring that Commonwealth troops are sufficiently trained and equipped the organisation would become increasingly valuable on the world stage.

Secondly, there does not appear to be a major need for the Commonwealth to involve itself in complex military interventions. It is now recognised that the reconstruction of government and civil society after a conflict is equally as important as an actual cease-fire in terms of restoring long term peace. As former Secretary-General Emeka Anyaoku put it: "the task of the peace builder is like that of the doctor. It is not just to remove the symptoms of ill-health but to eliminate the obstacles to long-term health and well being". ${ }^{152}$

With this in mind, it would seem sensible for the Commonwealth to confine its activities to situations like that in the Solomons, where the team sent in was a mixed group of civilians and soldiers who could not only ensure that peace was maintained but also help rebuild the infrastructure. It would be hard to conceive of the Commonwealth playing a role similar to that of ECOMOG in Sierra Leone, as it has neither the experience nor the resources. Furthermore, it could be damaging to the organisation's reputation as a quiet peacebroker if it continually emphasised its ability to stage a military intervention.

\section{Good Offices and Quiet Diplomacy}

The importance of quiet diplomacy to the Commonwealth is summed up in the following statement by a former Secretary-General: "[t]he Commonwealth cannot negotiate for the world; but it can help the world to negotiate". ${ }^{153}$ In line with this, the Commonwealth played a largely behind the scenes role in all of the three conflicts analysed. Despite the ways in which conflict has changed, the methods of quiet diplomacy and good offices appear to be as popular and successful now as they were twenty years ago. As Professor Slinn noted in 1989, "it is the essence of the Commonwealth method to proceed by informal, private contacts which may enable the parties to show more flexibility than in their public position". ${ }^{154}$ The benefits of having private negotiations have been

151 Don Mackay "New Zealand, The United Nations and Conflict Resolution" in Peter Greener (ed) Turning the Tide: A New Approach to Conflict Resolution (Auckland University of Technology, Auckland, 2001) 2.

152 Chief Emeka Anyaoku "Space in which Hope can Grow: The Commonwealth and Preventative Diplomacy" $<$ http://www.incore.ulst.ac.uk/home/publication/occasional/emeka.html> (last accessed 20 November 2001).

153 United Nations and Commonwealth Division, Ministry of Foreign Affairs and Trade "The Commonwealth: Looking Ahead" CHOGM 1999 Press Kit.

154 Peter Slinn "The Commonwealth and the Peaceful Settlement of Disputes" (1989) 15 Comm LB 573, 580. 
noted by numerous conflict resolution experts, with John Paul Lederach stating that it is often difficult to create sufficient trust between the parties in a highly visible environment. ${ }^{155}$

The Commonwealth has appeared to be fairly flexible as to who it dispatches on good offices missions. Although the Secretary-General would generally be the first choice, people like Sitiveni Rabuka and others who have a better knowledge of the conflict and the region have also been used. The role played by such people is generally the same regardless of the conflict: shuttling between both parties to the conflict, conveying messages and attempting to reach a common ground upon which both sides are willing to sit down and talk. The Commonwealth is as qualified as any other organisation to play this role, and if it can be successful in these attempts at quiet diplomacy then it prevents the conflict from escalating into something which it can no longer cope with. The benefits of quiet diplomacy are also especially important for dealing with conflicts in South Asia. As has been noted, many Asian nations are reluctant for outside parties to become involved, or even to recognise that a conflict is occurring. Therefore, if the Commonwealth can offer a service by which the conflict is kept off the media radar and is negotiated slowly and quietly, in accordance with regional tradition, then it may be more readily accepted by its South Asian members.

The quiet diplomacy area is therefore the Commonwealth's most powerful and effective tool for resolving conflict, and there are no substantive changes that need to be made. However, if the idea of regional secretariats is accepted this may even further improve the success rates of good offices missions. Regional groupings may be better placed than the central Secretariat in London to identify who would be the best person to mediate in the conflict. Another way in which quiet diplomacy could be improved would be to learn lessons from the development of organisations like the OSCE who have been effective in adjusting to the new patterns of conflict. The Commonwealth could consider establishing a position similar to that of the OSCE's High Commissioner on National Minorities (HCNM), whose primary task is to monitor conflict. The Foreign Policy Centre has already recommended the establishment of a Good Governance Commissioner (GGC) who would be a "focal point and catalyst for a democratic Commonwealth". ${ }^{156}$ Obviously the focus of the GGC would be different from that of the HCNM, but at the end of the day they would both be concerned with monitoring and preventing conflict. Another aspect of OSCE policy which the Commonwealth should consider emulating is that of long-term missions to countries of concern. It would be useful for the Commonwealth to have an "on the ground" presence in States like Sierra Leone and Sri Lanka where the conflict is continuing, so that all branches of the organisation are keep up to date with developments. Obviously such missions would not be permissible without the consent of the State concerned.

155 John Paul Lederach Building Peace: Sustainable Reconciliation in Divided Societies (US Institute of Peace Press, Washington DC, 1997) 44.

156 Kate Ford and Sunder Katwala Reinventing the Commonwealth (The Foreign Policy Centre, London, 1999) 29. 
In summary, the methods the Commonwealth has traditionally used to resolve disputes appear to be more than sufficient to deal with the new kind of conflict. Quiet diplomacy especially is as effective in intra-State conflicts as it is in inter-State disputes. However, there are also ways in which the Commonwealth can modify their traditional methods in order to be more successful. The idea of regional secretariats is one such modification which could provide enormous benefits to the organisation, and enhance its ability to resolve conflicts. Furthermore, CMAG is still grappling with its mandate and has to focus on how it can best act to prevent breaches of the Harare Declaration. Also, the idea of giving the organisation peacekeeping capabilities should be considered and lessons should be taken from the experience of other organisations like the OSCE. At the end of the day, however, the authors of the Foreign Policy Centre report were correct when they stated that "the biggest question is not whether the Commonwealth can change, but whether its members want it to". 157

\section{CONCLUSION}

It is clear that the Commonwealth has much to offer in terms of conflict resolution abilities. Not only does it regularly bring together 54 diverse nations, but it also provides a link between these States, regional organisations, and the United Nations. The ability of other organisations to take on some of the responsibilities of the United Nations is becoming increasingly important as conflict patterns become more complex. Although regional organisations are so far adapting reasonably well to this new world order, the presence of an organisation like the Commonwealth, which can not only become directly involved in conflict resolution but can also act as a coordinating body, should not be underestimated.

Despite challenges such as secession and sovereignty, the Commonwealth seems to be going from strength to strength with respect to its conflict resolution abilities. Its use of quiet diplomacy especially has been successful, as have the organisation's efforts to solve conflicts using a regional approach. However, the Commonwealth has indicated its intention to remain an adaptable organisation and there are several changes that could be made to ensure that the Commonwealth keeps pace with changing times. The regional approach to conflict resolution could be taken further by establishing regional secretariats which could not only act to monitor conflicts but could also ensure that timely and appropriate action is taken by the organisation. CMAG is at this point still a fairly new body and is grappling with its mandate. It needs to consider taking a broader approach to its work, and looking at a wider range of conflicts. The Commonwealth should also consider the option of becoming involved in peacekeeping, though if it does so this should be a fairly low-key activity and it should leave major military operations to those organisations better prepared to coordinate them. Finally, the Commonwealth should always keep a watchful eye on other

157 Ford and Katwala, above, 61. 
organisations, such as the OSCE, who are developing their conflict resolution mechanisms, to see what lessons it can learn.

The Commonwealth has come a long way from the days when it was seen as an old boys club which met occasionally for "fireside chats". Although many still see it as a talking shop and a colonial relic, it is clear that the Commonwealth is actually very much a dynamic organisation capable of delivering benefits to its member States. Indeed the organisation seems to have made excellent use of the fact that it has retained some methods, such as quiet diplomacy, which could be seen as old-fashioned and traditional but which are also generally accepted by all States. Furthermore, it has taken the important step of establishing CMAG to ensure that major breaches of human rights within the Commonwealth do not go unnoticed. The organisation has achieved an excellent balance between traditional and modern methods and, as long as it continues to adapt itself to changing circumstances, the Commonwealth will play a positive conflict resolution role for years to come. 
(2003) 34 VUWLR 